\title{
INFLUENȚA CARACTERISTICILOR MĂRII NEGRE ASUPRA OPERAT,IILOR ÎNTRUNITE
}

\author{
Dr. Florin NISTOR* \\ Dr. ing. Lucian-Valeriu SCIPANOV**
}

In cadrul acestui demers, se propune identificarea unor caracteristici militare ale Mării Negre, din punctul de vedere al unei mări semiînchise, caracteristici care pot influența desfășurarea unei acțiuni militare în context întrunit. Astfel, se va sublinia rolul și locul structurilor de forțe navale prin valorificarea potențialului optim pentru sprijinul acțiunilor de la litoral, desfășurate de structurile de forțe terestre. Noutatea acestui demers este subliniată de faptul că cercetarea are la bază rezultatul cooperării specialiștilor din cadrul Forțelor Navale Române cu specialiști din cadrul Forțelor Terestre, obținut în urma desfășurării unor jocuri de război și utilizării altor instrumente de cercetare, specifice domeniului științei militare. Originalitatea constă tocmai în faptul că misiunile particulare ale Forțelor Navale pe timpul sprijinului acordat Forțelor Terestre au fost identificate de autori prin experiența acumulată în cadrul unor exerciții desfășurate în cadrul Universității Naționale de Apărare „Carol I”. Produsul obținut va realiza acea corespondență intre caracteristicile Mării Negre și capabilitățile necesare, destinate manifestării puterii maritime, printr-un răspuns adecvat în cazul unor acțiuni militare întrunite, care să contribuie la sprijinul intereselor naționale pe mare și pe fluviu.

Cuvinte-cheie: mări inchise/semiînchise; Marea Neagră; caracteristici militare; operații întrunite; forțe navale; forțe terestre.

* Comandor Florin NISTOR este profesor universitar dr. în cadrul Departamentului forțe navale, Facultatea de comandă și stat major, Universitatea Națională de Apărare „Carol I”. E-mail: ronavy.florin@yahoo.com

**Comandor Lucian-Valeriu SCIPANOV este conferențiar universitar dr. ing. în cadrul Departamentului forțe navale, Facultatea de comandă și stat major, Universitatea Națională de Apărare „Carol I”. E-mail: shcipio@yahoo.com 


\section{Introducere}

Scopul acestui articol este acela de a identifica acele caracteristici ale Mării Negre care pot influența forma și modul de acțiune, forțele și mijloacele, metodele și procedeele de luptă, întrebuințate în cadrul acțiunilor militare desfășurate în context multinațional, cu capabilități naționale destinate. Prin acest demers, va fi identificată contribuția capabilităților navale pentru sprijinul acțiunii structurilor de forțe terestre (corp armată, divizie, brigadă) în zona de responsabilitate a Forțelor Navale Române (FNR). Având în vedere că prioritatea FNR o reprezintă zona maritimă și riverană, Marea Neagră, în principal, și Fluviul Dunărea, în continuare, acest aspect reprezintă punctul central al analizei. Raportat la acesta, se va urmări identificarea unor aspecte cheie în cadrul colaborării dintre specialiștii unor structuri de forțe terestre (în continuare, se va folosi termenul generic de „forțe terestre") și forțe navale, pe baza lecțiilor învățate, a rezultatelor obținute în cadrul cercetărilor, a jocurilor de război, a produselor diseminate, precum și a altor aspecte relevante rezultate din experiența autorilor în domeniul artei operative maritime. Punctul de plecare în cadrul acestui demers îl constituie poziția geografică a țării noastre, în raport cu cele mai experimentate opinii ale unor specialiști în domeniu, care au identificat cele mai importante caracteristici ale mărilor închise/ semiînchise. Din punctul de vedere al autorilor, aceste aspecte obligă specialiștii în domeniul strategiei militare să identifice acele soluții adecvate de răspuns, în raport cu interesele naționale în regiunea Mării Negre. În domeniul maritim, este oportun ca aceste decizii să determine alegerea celor mai eficiente măsuri de răspuns și mijloacele necesare și suficiente pentru a le implementa cu succes. Din acest punct de vedere, așteptarea autorilor este de a realiza acea corespondență între caracteristicile Mării Negre și capabilitățile necesare, destinate manifestării puterii maritime printr-un răspuns adecvat în cazul unor acțiuni militare întrunite, care să contribuie la sprijinul intereselor naţionale pe mare și pe fluviu.

În general, poziția geografică a unei țări riverane, cu litoral într-o mare închisă/semiînchisă, permite sau facilitează manifestarea puterii maritime. Din această perspectivă, componente ale puterii maritime, cum ar fi poziția geografică, economia și voința politică, pot să-şi diminueze importanța dacă cel puțin una nu este de interes, în comparație cu contextul geografic al mării închise/semiînchise. $\mathrm{Cu}$ toate acestea, avantajele ieșirii la o mare închisă/semiînchisă nu trebuie minimizate, chiar dacă o componentă a puterii maritime nu este exploatată sau evidențiată în mod clar, deoarece celelalte componente pot compensa această deficiență. Pentru a vedea care este legătura între modul de manifestare a puterii maritime, implicit a puterii navale, cu modul de acțiune al unei flote în scopul manifestării interesului național pe mare și fluviu, în cadrul acestui articol, au fost stabilite următoarele obiective: 
- prezentarea principalelor caracteristici ale mărilor semiînchise;

- identificarea caracteristicilor Mării Negre (ca mare semiînchisă) din punctul de vedere al războiului modern;

- evidențierea contribuției forțelor navale la acțiunile structurilor de forțe terestre care desfășoară acțiuni militare în apropierea litoralului;

- realizarea corespondenței dintre caracteristicile acțiunilor militare desfăşurate în mări semiînchise și modul de acțiune, forțele și mijloacele destinate, metodele și procedeele de luptă ale forțelor navale.

După cum se observă, obiectivele acestui demers sunt în legătură directă cu caracteristicile militare ale mărilor semiînchise, dintr-o perspectivă a caracteristicilor războiului modern. Analiza este bazată pe experiența autorilor în domeniu, ca urmare a dezvoltării cercetării în domeniul artei operative moderne, rezultatelor jocurilor de război pentru scenarii de luptă în mediile maritim și riveran, la suprafață, în aer și sub apă. Această experiență a fost dobândită prin participarea și contribuția la activităţi desfășurate de-a lungul anilor în Universitatea Naţională de Apărare „Carol I", exerciții, studii, analize, mese rotunde sau discuții purtate în cadrul seminariilor ori cu alte ocazii, între specialiști.

Din punctul de vedere al manifestării puterii navale, dacă realizăm o analiză atentă a celor mai faimoase acțiuni militare din istorie, putem observa că mările închise/semiînchise au fost locul unor acțiuni navale desfăşurate, preponderent, în conflictele regionale și mai puțin în conflictele majore. În această idee, celebrul profesor Milan Vego (profesor la Colegiul de Război al Forțelor Navale), Newport, Rhode Island) subliniază că cele mai frecvente scenarii posibile pentru mări închise/ semiînchise sunt:

- „război limitat sau conflict regional;

- un război restrâns la o anumită zonă geografică și lupta între o putere majoră și una sau mai multe puteri minore sau un război între puterile majore pentru a atinge obiective strategice limitate" 1 .

$\mathrm{Cu}$ alte cuvinte, este admis faptul că, în viitor, o mare semi-închisă va fi o zonă de operații secundară în cadrul unui teatru de război în care, de cele mai multe ori, vor fi implicaţi doi actori mari cu interese regionale. De asemenea, este de așteptat ca actori regionali mai mici să coaguleze alianțe ori coaliții împotriva unor actori regionali majori. Din acest punct de vedere, se va urmări să se identifice acele capabilități naționale și modul de acțiune asociat acestora, în funcție de caracteristicile războiului modern în mări semiînchise, care pot răspunde unor ameninţări dinspre mare, în regiunea Mării Negre.

Pentru aceasta, în continuare se vor prezenta principalele rezultate ale unei analize criteriale a principalelor caracteristici ale unei mări semiînchise, desfășurată

${ }^{1}$ Milan N. Vego, Naval Strategy and Operations in Narow Seas, US Naval War College, Newport, Rhode Island, Ed. Routledge, 2013, p. 11. 
în scopul realizării acestei lucrări. De asemenea, se va efectua o analiză a principalelor caracteristici militare ale Mării Negre, prin care se intenţionează să se valideze trei ipoteze de cercetare, având la bază obiectivele cercetării.

\section{Principalele caracteristici ale unei mări închise/semiînchise}

Din punct de vedere militar, în funcție de anumite criterii specifice, se pot evidenţia principalele caracteristici ale unei mări semiînchise:

- după criteriul spațial: reducerea spațiului/zonei de acțiune, datorită autonomiei platformelor, dar și reducerea distanțelor față de obiectivele militare;

- după criteriul acțional: creșterea intensității acțiunii, stabilirea rapidă a deznodământului acțiunii;

- după criteriul temporal: timpi reduși de acțiune, datorită distanțelor relativ scurte, în raport cu viteza de acțiune a platformelor moderne;

- după criteriul informațional: contribuția tuturor forțelor participante la realizarea, în timp real, a Imaginii Maritime Recunoscute (Recognized Maritime Picture/RMP).

Având în vedere aceste criterii pentru analiza unei mări semiînchise, din punct de vedere militar s-ar deduce că:

- posibilitatea confruntărilor majore este minimizată, dar nu este exclusă acțiunea militară de intensitate redusă: bătălii navale, lovituri, ciocniri;

- acțiunile militare se desfășoară în contextul operațiilor de pace, promovarea diplomației navale etc.;

- acțiunile militare sunt direct puternic influențate de hidrografia mării semiînchise, adâncimi, salinitate, curenți etc.

Prin urmare, în opinia autorilor, acestea vor fi considerate ipoteze de lucru în cercetările ulterioare. De asemenea, în contextul procesului de planificare asociat unor conflicte armate de amploare, se poate considera necesar a se lua în calcul unele scenarii care se pot desfășura în mări semiînchise. Scenariile posibile pentru un conflict limitat pe mări semiînchise pot aborda una dintre următoarele teme/ situații de planificare:

- „un război cu intervenție limitată;

- un război limitat între două puteri majore care evoluează într-un conflict naval complet;

- dezorganizarea transporturilor maritime ale inamicului și/sau a neutrilor în strâmtorile internaţionale;

- o dispută cu privire la zona economică exclusivă ZEE;

- un conflict local într-o mare închisă/semiînchisă tipică, lupta între două sau mai multe puteri minore, în timp ce puterile majore rămân strict neutre"2, chiar dacă ${ }^{2}$ Milan N. Vego, op.cit., p.11. 
o putere majoră poate oferi sprijin unuia dintre participanți, în funcție de interesele sale sau ale partenerilor.

$\mathrm{Ca}$ urmare, pot fi extrase câteva concluzii preliminare, care completează corolarul caracteristicilor mării semiînchise:

- este facilitat războiul electronic și cibernetic; medie;

- se așteaptă utilizarea, în principal, a rachetelor cu rază de acțiune scurtă și

- se preconizează desfășurarea unor grupări navale de mici dimensiuni;

- sunt vizate obiective limitate și aici ne putem referi la anumite caracteristici ale unui obiectiv: strâmtori);

- spațial-geografice (zone maritime, porturi, linii de comunicații, insule,

- destinaţia obiectivului (în principal economic, militar etc.);

- importanța obiectivului (nivel tactic, operativ sau strategic etc.).

Având în vedere concluziile parțiale enunțate, în continuare, se vor prezenta, pe scurt, rezultatele analizei caracteristicilor militare ale Mării Negre.

\section{Principalele caracteristici militare ale Mării Negre}

Având identificate principalele caracteristici ale unei mări semiînchise, susținute de criterii de analiză ancorate în domeniul militar, corelate cu concluziile parțiale prezentate, în continuare, se va efectua o analiză a principalelor caracteristici militare ale Mării Negre.

Marea Neagră este considerată o mare semiînchisă, datorită faptului că accesul între aceasta și Oceanul Planetar se face, în principal, prin strâmtorile Bosfor și Dardanele. Nu trebuie să neglijăm faptul că Marea Neagră are acces la Oceanul Planetar și prin coridorul VII paneuropean, Rihn-Main-Dunăre sau canalele rusești, cu limitările impuse de pescajul minim.

Având în vedere că principalele caracteristici ale unei mări semiînchise au fost definite prin prisma acțiunilor militare, obiectivul acestui capitol se va realiza printr-o analiză structurată pe nivelurile artei militare: strategic, operativ și tactic.

\subsection{Nivelul strategic}

Principalele aspecte care trebuie luate în calcul de către decidenții militari și care produc efecte la nivel strategic sunt prezentate în continuare.

În primul rând, acțiunile de luptă pot fi efectuate cu o mare intensitate (high intensity) ${ }^{3}$, simultan, pe întreaga suprafață a Mării Negre. Uneori, datorită autonomiei navelor moderne, teatrul acțiunilor militare se poate extinde în mările

${ }^{3}$ Milan N. Vego, op.cit., p. 12. 
adiacente, cum ar fi Marea Mediterană, Azov sau Marea Baltică, inclusiv prin implicarea capabilităților de la litoral. De-a lungul istoriei, Marea Neagră a mai fost scena acțiunilor navale în conflicte regionale (local conflict ${ }^{4}$ ) sau în conflicte majore, ca zonă secundară de operații.

În al doilea rând, loviturile aeriene sunt decisive în comparație cu acțiunile forțelor navale sau terestre. În general, puterea aeriană reprezintă un instrument de manifestare a puterii militare mult mai eficient decât puterea navală. În consecință, puterea aeriană poate fi decisivă în războiul pe mare. Acțiunile militare decisive vor fi caracterizate de utilizarea predominantă a armelor de înaltă precizie (rachete ${ }^{5}$ sau sisteme aeriene fără pilot) - fundamentul conceptului A2AD. Astfel, din acest punct de vedere, trebuie să se țină cont de faptul că grupările navale sunt foarte vulnerabile la loviturile cu rachete și, pentru aceasta, au nevoie de sprijinul unui puternic sistem de foc antiaerian.

Pe de altă parte, o acțiune navală are, de regulă, un rol de nivel operativ-tactic, dar nu se exclude rolul decisiv pe care îl poate juca o bătălie navală în evoluția acțiunilor de nivel strategic. Aici, poate fi dat un exemplu concret: recâștigarea controlului asupra mării, menținând în același timp superioritatea aeriană, poate influența major rezultatul întregului conflict prin avantajele directe și indirecte care rezultă din realizarea acestui deziderat.

La nivel strategic, unul dintre principalele obiective ale oricărui participant la o acțiune militară este redeschiderea comunicațiilor maritime și protecția acestora. Spre exemplu, Turcia modernă, într-o postură a succesorului imperiului bizantin și, mai târziu, a Turciei musulmane, deține controlul incontestabil al strâmtorilor ${ }^{6}$. Prin urmare, au dominat comerțul în regiunea Mării Negre și sunt capabili să controleze incursiunea în zona Mării Negre. În acest caz, Convenția de la Montreux devine un instrument strategic de negociere, cu toate implicațiile care decurg din aceasta.

În cele din urmă, principalele acțiuni militare vor avea loc lângă coastă, pe litoral, pe apă și uscat, în porturi și baze, pe comunicații maritime și terestre. Milan Vego sublinia: „Una dintre sarcinile principale ale strategiei navale în timp de pace este de a construi sau achiziționa un număr suficient de baze navale și porturi pentru a permite forțelor să realizeze obiectivele strategice naționale și militare în timp de război" " , în consecință, deținerea de baze navale bine apărate, conectate cu rețeaua de comunicații, cu posibilități de aprovizionare, reprezintă un obiectiv strategic.

Prin urmare, ca o concluzie preliminară, Marea Neagră va rămâne o zonă secundară de acțiuni militare. De aici și rolul forțelor navale pentru misiuni specifice, mai puțin decisive la nivel strategic, dar importante la nivel operativ și tactic.

\footnotetext{
${ }^{4}$ Ibidem, p. 11.

${ }^{5}$ Ibidem, p. 12.

${ }^{6}$ Ibidem, p. 17.

${ }^{7}$ Ibidem, p. 61.
} 


\subsection{Nivelul operativ}

Având în vedere cele prezentate, se poate afirma faptul că geometria spaţiului de luptă în mări semiînchise este diferită de cea a altor tipuri de mări.

Teoretic, principalele componente ale teatrului de operații maritime sunt: „bazele de operații, obiectivele fizice, punctele decisive, liniile de operații, liniile de comunicații”" În cazul mărilor semiînchise ,aceste elemente sunt situate destul de dens datorită distanțelor mult mai mici" ". Astfel, rolul planificatorului militar este de a identifica efectele maxime pe care le pot produce acțiunile forțelor navale asupra componentelor teatrului de operații maritime, în funcție de acțiunile celorlalte componente ale forței întrunite.

Din punct de vedere spațial (obiective fizice), dacă ne referim la această componentă a teatrului de operații maritime, o țară poate fi situată astfel încât să poată controla total sau parțial marea, fie ocupând o poziție la o distanță convenabilă față de strâmtori, fie deținând strâmtorile. În timp de pace, spațiul maritim este controlat prin mijloace diplomatice, inclusiv prin coagularea de alianțe sau coaliții între riverani sau alți actori. Pe timp de război, strâmtorile sunt mult mai importante. Controlul spațiului maritim este, în acest caz, un obiectiv de nivel operativ.

În termeni generali, conceptele controlul mării și limitarea folosirii mării reprezintă în principal, controlul comunicațiilor maritime (liniilor de comunicații). În mările semiînchise, din cauza distanțelor mici, o flotă care acționează la litoral poate contribui uşor și semnificativ la obținerea controlului mării (inclusiv controlul spațiului aerian și terestru adiacent litoralului), cu excepția spaţiului submarin (dacă un potențial inamic deține o flotă de submarine). În acest caz, o flotă special destinată luptei antisubmarin, care include capabilități de luptă sub apă (submarine, UUV, mine, sisteme de supraveghere sub apă etc.), este imperios necesară. Prin urmare, în cazul mărilor semiînchise, considerăm potrivite utilizarea și aplicarea conceptului Controlul mării decât Comanda mării. În cazul forțelor navale, se dovedesc oportune utilizarea și aplicarea conceptului Limitarea folosirii mării, mult mai adecvat capabilităţilor existente.

Plecând de la enunțul „Cea mai mică marină poate complica controlul mării pentru o marină puternică" 10 , din acest punct de vedere, este foarte ușor să deții controlul mării în mări deschise și foarte dificil, dar este aproape imposibil în marea semiînchisă. Și acest lucru nu se datorează prezenței unei flote la litoral, ci prezenței sistemelor de apărare costieră, a rachetelor de coastă și a sistemului de baraje de mine, inclusiv amenajările genistice sau amenajările împotriva forțelor de debarcare.

În cazul punctelor decisive, identificate ca urmare a aplicării artei operative pe timpul planificării acțiunilor militare, teoria descrie că între fazele operației

${ }^{8}$ Idem.

${ }^{9}$ Idem.

${ }^{10}$ Milan N. Vego, op.cit., p. 111. 
maritime există anumite pauze operative care apar din cauza ritmului crescut al operațiilor, fapt care duce la reducerea timpului alocat executării acestora. În opinia noastră, în mările semiînchise, aceste pauze operative pot fi inutile. „Intensitatea mare a acțiunii navale va duce la o schimbare rapidă a unei situații. Trecerea bruscă de la ofensivă la apărare și viceversa" " situația operativă poate suferi schimbări radicale și frecvente ${ }^{12}$, aceasta fiind $\mathrm{o}$ consecință a caracteristicii războiului naval modern, desfășurat de către componenta aero-navală. Însă, nu trebuie minimalizate acțiunile cu caracteristici ale războiului hibrid, „războiul hibrid poate fi suma tuturor acțiunilor indiferent de natura lor”"13, aspect care ne determină să considerăm că pe mare acesta capătă caracteristici particulare. Dar este obligatoriu să subliniem că manevrabilitatea forțelor aeriene pe mare este un avantaj. De aceea, punctele decisive trebuie identificate în funcție de aceste schimbări de situație sau avantaje.

De asemenea, un instrument care oferă avantaje strategic-operative este războiul electronic și, mai recent, războiul cibernetic. Utilizarea războiului electronic poate face dificilă sau imposibilă utilizarea senzorilor și a armelor ghidate ${ }^{14}$. Mai mult decât atât, utilizarea vehiculelor fără pilot poate fi perturbată.

Dintre toate aspectele caracteristice de la nivel operativ, o concluzie se conturează foarte precis, și anume: există o dependență biunivocă între acțiunile forțelor navale de pe mare și la litoral și acțiunile forțelor terestre de la coastă care, la rândul lor, depind de rezultatul acțiunilor forțelor aeriene în cadrul operației întrunite pentru menținerea unui nivel minim de control al spațiului aerian. În opinia noastră, aceasta reprezintă una dintre cele mai importante concluzii ale acestui demers.

\subsection{Nivelul tactic}

Din punct de vedere tactic, se poate afirma că viteza mare a navelor moderne, abilitatea de a combina manevra și puterea de foc, reprezintă avantaje majore care oferă superioritate în mediul de operare, în special prin posibilitatea de a realiza surprinderea adversarului. Acțiunile militare au loc mai ales noaptea, în special la răsărit și apus. În mările semiînchise, desfăşurarea forțelor de luptă la litoral și manevra forțelor tactice pot fi mai dificile. La suprafață, după fiecare atac aerian, refacerea/regruparea forțelor este dificilă, întrucât timpul disponibil între două atacuri succesive nu este suficient pentru a reorganiza dispozitivul de luptă și nici

\footnotetext{
${ }^{11}$ Ibidem, p. 12.

${ }^{12}$ Idem.

${ }^{13}$ Daniel ROMAN, Cristian-Octavian STANCIU, "The operational art in the context of range of threats specific to the contemporaty Security environment", GlobState III, Web Conference 16-20 November 2020, Polish Armed Forces Doctrine \& Training Centre Kazimierz Wielki University, p. 123.

${ }^{14}$ Milan N. Vego, op.cit., p. 12.
} 
pentru completare. Raportat la capabilitățile tactice, forțele aeriene cu baza la sol reprezintă cea mai mare amenințare la adresa grupărilor navale (TGs) pe mare sau în porturi, inclusiv la adresa facilităţilor portuare. Se poate extrage deja o concluzie parțială, și anume, confruntarea navală în mări semiînchise poate fi realizată prin desfășurarea unui TG eterogen. De asemenea, misiunea, scopul și durata acțiunii sunt definite de obiective limitate, bine stabilite în timp și spațiu.

Având în vedere caracteristicile militare ale Mării Negre, reamintim unele acțiuni militare care sprijină concluziile parțiale prezentate: acțiunea grupării navale Datoria asupra navelor georgiene, acțiunea hibridă din Crimeea, acțiunile din jurul strâmtorii Kerci, sechestrări de nave și acțiuni navale la litoralul regiunii DonetzLuganks, acestea fiind unele dintre cele mai recente exemple. Dacă analizăm aceste fapte, vom constata că multe dintre caracteristicile militare ale Mării Negre au fost luate în considerare de către planificatorii militari ai acestor acțiuni, reușita acțiunilor fiind o dovadă palpabilă.

\section{Aspecte ale sprijinului forțelor terestre în acțiuni militare la coastă}

\subsection{Sprijinul forțelor terestre în acțiuni la litoral}

În primul rând, forțele terestre trebuie să țină cont de faptul că Pregătirea informativă a câmpului de luptă (Intelligence Preparation of the Battlefield/IPB) trebuie efectuată pe întreaga suprafață a Mării Negre, acțiunile viitoare depinzând de zona de interes informativ.

În al doilea rând, acțiunea forțelor navale pentru realizarea RMP este o acțiune de sprijin a forțelor terestre. Barajele de mine reprezintă o zonă No Go în IPB-ul forțelor terestre.

În cazul unei operații amfibii, componenta navală poate informa permanent forțele terestre cu privire la evoluția fazelor operației.

De asemenea, acțiunile forțelor navale pot determina adversarul să schimbe cursul de acțiune (COA). Printre aceasta, se pot menționa acțiuni de minare, lovituri de artilerie, utilizarea sistemelor de rachete de coastă etc.

În ceea ce privește lupta împotriva forțelor amfibii, forțele navale pot contribui la respingerea, întârzierea, canalizarea și/sau distrugerea forțelor inamice de debarcare. Contradebarcarea este o acțiune specifică la litoral pe care forțele navale o pot desfășura atât pe mare, cât și la gurile fluviului.

În acțiunile militare la litoral, capabilităţile forțelor navale reprezintă forța de sprijin pe flancul forțelor terestre. Prin urmare, acțiunile forțelor navale de pe mare depind întotdeauna de acțiunea forțelor terestre la țărm.

În general, forțele navale contribuie și sunt capabile să realizeze sprijinul forțelor terestre în acțiunile de la litoral prin:

- acțiuni sistematice (prezență, descurajare, supraveghere); 
- suport informativ;

- realizarea și actualizarea RMP;

- modelarea câmpului tactic;

- limitarea acțiunilor inamice;

- întârziere, canalizare;

- provocarea de pierderi inamicului;

- impunerea inamicului de a alege un alt COA nefavorabil etc.

\subsection{Sprijinul forțelor terestre în acțiuni riverane}

Similar subcapitolului anterior, în zona riverană, IPB-ul este comun forțelor terestre și forțelor navale.

În defensivă, zona riverană (Fluviul Dunărea, zona lagunară, Delta Dunării, litoralul aferent) este, în principal, zonă Slow Go. Minarea punctelor de trecere fluviale obligatorii devine No Go în comunicațiile fluviale.

În ofensivă, forțele terestre constituite în forțe de debarcare riverane, susținute pe flanc de forțele navale, maritime sau fluviale, au rolul de detaşamente de întoarcere. Contraatacurile simultane din mai multe direcții cu subunități tactice reprezintă o caracteristică a operației riverane.

Din punctul de vedere al comenzii și controlului (C2) forțelor, caracterul descentralizat al acestei funcțiuni de luptă este mai puternic în contextul operației riverane.

De asemenea, principala acțiune a forțelor riverane o reprezintă acțiunea de sprijin al forțelor terestre de la litoral și pe comunicațiile fluviale:

- sprijinul forțelor terestre în capul de pod;

- asigurarea dragajului și marcarea culoarelor prin barajele de mine;

- minarea și izolarea zonelor riverane;

- asigurarea transportului trupelor din zona de ambarcare în zona de debarcare;

- debarcarea în luptă a forțelor de desant riveran;

- sprijinul prin foc al forțelor de desant riveran pe timpul debarcării și acțiunilor ulterioare;

- asigurarea aprovizionării a forțelor debarcate;

- asigurarea retragerii forțelor de desant riveran, respinse din capul de pod.

\section{Concluzii}

Pe baza argumentelor prezentate, suntem în măsură să subliniem rolul și locul Forțelor Navale Române, ca cel mai vizibil instrument național de manifestare a puterii navale. Dimensiunea grupărilor navale (TF/TG) pentru mările semiînchise nu este atât de mare, în comparație cu o grupare navală destinată pentru o operație 
maritimă în marea liberă, cu spații mult mai largi. Acest lucru justifică atenția asupra acțiunilor forțelor navale ale statelor în mările care se învecinează cu Marea Neagră (Azov, Marmara și Mediterana).

Confruntarea navală în Marea Neagră poate fi realizată prin desfășurarea unei grupări navale eterogene (TG eterogen). Apărarea împotriva forțelor inamice de debarcare, maritime sau riverane, poate fi rezolvată print efort comun, în cadrul apărării colective. De aici rezultă faptul că operațiile în marea semiînchisă sunt clar diferite de cele desfăşurate în marea liberă. Astfel, structura unei grupări navale (TF/TG) în marea semiînchisă este diferită de structura unei grupări navale care operează în marea liberă.

Operația decisivă poate viza distrugerea forței de debarcare inamice, efortul principal fiind realizat de către forțele terestre. Regiunea mării semiînchise devine câmp de luptă integrat - acțiunile de luptă vor avea loc simultan în mediul terestru, aerian și maritim. Din acest punct de vedere, nu putem minimaliza rolul unei componente a armatei, a forțelor terestre, aeriene sau navale. În aceste condiții, considerăm că dependența dintre categoriile de forțe care acționează la litoral este mult mai accentuată, forțele aeriene având o importanță de netăgăduit.

$\mathrm{Cu}$ toate acestea, cel mai important aspect al cercetării evidențiază dependența dintre acțiunile forțelor terestre, navale și aeriene în acțiunile militare din regiunea Mării Negre, considerată o mare semiînchisă. Subliniem, ca aspect de noutate și originalitate, că misiunile forțelor navale în sprijinul structurilor de forțe terestre au fost identificate prin experiență proprie și în cadrul multor exerciții desfășurate în cadrul Universității Naționale de Apărare „Carol I”.

\section{BIBLIOGRAFIE:}

1. ***, Colectiv de autori, Seria de exerciții Tactical command exercise in education command post MUNTENIA 2019, 2020, Universitatea Națională de Apărare „Carol I”, București, România, Bibliografie militară, cote: DA 418/NS; DA 326/NS.

2. ***, Scenariul exercițiului prin simulare „MAGISTERIUM”, Universitatea Națională de Apărare „Carol I”, București, România, Aplicații, cota: APL 235/2021.

3. ROMAN, Daniel; STANCIU, Cristian-Octavian, "The operational art in the context of range of threats specific to the contemporaty Security environment", GlobState III, Web Conference 16-20 November 2020, Polish Armed Forces Doctrine \& Training Centre Kazimierz Wielki University.

4. SCIPANOV, Lucian-Valeriu; MAXIM, Valentin, „Considerations regarding on the russian doctrine for a new warfare model in the Black Sea region", Impact strategic, Editura Universității Naționale de Apărare „Carol I”, nr. 78/2021, vol. 1. 
5. SCIPANOV, Lucian-Valeriu; NISTOR, Florin, Considerations on the military actions conducted in the North of Black Sea, Buletinul Universității Naționale de Apărare „Carol I”, vol. 2, nr. 2, București, România, 2015.

6. VEGO, Milan N., Naval Strategy and Operations in Narow Seas, US Naval War College, Newport, Rhode Island, Ed. Routledge, 2013. 